\title{
Genetic diversity patterns in Phragmites australis at the population, regional and continental scales
}

\author{
Carla Lambertini ${ }^{\text {a,b,*, Mats H.G. Gustafsson }}{ }^{\text {a }}$, Jane Frydenberg ${ }^{\text {a }}$, \\ Maria Speranza ${ }^{\mathrm{b}}$, Hans Brix ${ }^{\mathrm{a}}$ \\ ${ }^{a}$ Department of Biological Sciences, Aarhus University, Denmark \\ ${ }^{\mathrm{b}}$ Department of Agro-Environmental Sciences and Technologies, University of Bologna, Italy \\ Received 20 November 2006; received in revised form 1 September 2007; accepted 8 October 2007 \\ Available online 12 October 2007
}

\begin{abstract}
Genetic diversity, population structure and interrelationships were investigated in eight populations of the common reed, Phragmites australis, in the Po Plain, Italy, by means of amplified fragments length polymorphisms (AFLPs) and random amplified polymorphic DNAs (RAPDs). Patterns of genetic diversity were analysed in relation to size, age and degree of human impact in the wetlands and compared with that of a distant population in Romania. Genetic distances between Po Plain clones and geographically distant clones were measured to determine the geographical extent of the gene pool.

Nearly all populations studied are polyclonal and little correlation was found between genetic diversity and size, age and degree of human impact on the wetlands. One large ( 86 ha) monoclonal stand occurred in an old wetland with rather stable environmental conditions over a long time period, whereas polyclonal stands were younger and characterized by disturbance. On the interpopulation level it was not possible to differentiate between Po Plain populations and the Romanian population, indicating that a very extensive gene pool exists in Europe, to which both Po Plain and Romanian populations belong. There is however a certain degree of genetic structure among the populations that is not correlated with geographic distance, but is most likely related to $P$. australis colonization dynamics. A significant "stepwise" increase in average genetic distances was observed between clones $>500$ and $>1500 \mathrm{~km}$ distant suggesting some kind of genetic pattern on a very large scale. Based on these results, $P$. australis populations in Europe could be considered members of a single meta-population.
\end{abstract}

(C) 2007 Elsevier B.V. All rights reserved.

Keywords: Phragmites australis; AFLP; RAPD; Genetic diversity; Population structure; Genetic relationship; Genetic distance; Meta-population; Common reed; Wetland

\section{Introduction}

Phragmites australis (Cav.) Trin ex Steud., the common reed, is a perennial emergent aquatic plant with a nearly worldwide distribution. Throughout most of its range, it typically forms closed, monodominant stands in the littoral zone of lakes, along rivers and in marshes of various kinds (Brix, 1999; Brix and Cizkova, 2001). The annual stems develop from an underground perennial rhizome system, which is responsible for the rapid vegetative expansion of the species. Sexual reproduction occurs but is pollen limited and affected by partial self-incompatibility (Ishii and Kadono, 2002).

\footnotetext{
* Corresponding author at: Aarhus University, Department of Biological Sciences, Plant Biology, Ole Worms Allé, Bld. 115, Denmark. Tel.: +458942 4713; fax: +458942 4747 .

E-mail address: carla.lambertini@biology.au.dk (C. Lambertini).
}

Varying degrees of clonal diversity have been found in $P$. australis populations, ranging from monoclonal to polyclonal (Neuhaus et al., 1993; Koppitz et al., 1997). The colonization of a wetland by $P$. australis typically begins on the shores where numerous seeds germinate. Colonization then continues with the vegetative expansion of the seedlings, and as spaces between plants are progressively filled in, the clones start to compete for space. This process may result in a complex spatial distribution, where different clones intermingle. Clonal diversity is still high at the "propagation and establishment stage", while it decreases during the subsequent "stationary stage", in which a small number of clones well adapted to the local environmental conditions prevails (Koppitz and Kühl, 2000). Low clonal diversity and monoclonal populations could be the result of such a selection process and be an indication that stands have grown under stable conditions for a long time (Watkinson and Powell, 1993). Seedling recruitment is 
generally considered to occur only during "windows of opportunity" such as after a physical disturbance (Eriksson, 1997; Clevering, 1999). Favourable conditions for seed germination and seedling growth have been observed to occur after clearing of existing vegetation on bare riverbanks and after episodic drawdowns (Weisner et al., 1993). Seedling establishment is not very frequent in mature $P$. australis populations (Barrett et al., 1993). This and the clonal growth described above limit opportunities for gene flow within populations of $P$. australis and decrease genetic diversity.

Little is known about the extent and mechanics of gene flow via seeds and pollen between populations of P. australis. New wetlands are often rapidly colonized by $P$. australis even in areas far from reproducing stands. Long-distance gene flow may thus be an important factor in shaping genetic variation patterns.

In the Po Plain, northern Italy, numerous $P$. australisdominated wetlands occur that are connected by a complex network of natural rivers and channels with regulated flow. Some are very old and represent the remnants of the extensive reed-dominated marshes that once covered the Po floodplain. Today most of the plain is drained and intensively cultivated. In the 1990s a number of wetlands were restored in compliance with European Community policies, which provided financing for transformation of croplands into wetlands. Today these wetlands are primarily maintained as hunting reserves. The management, mostly in the form of harvesting, may affect the genetic structure and diversity of $P$. australis populations as it indirectly creates opportunities for the seedling establishment, modifies the clonal architecture of populations, and affects the mating and dispersal opportunities (Charpentier, 2002). We expect to find high clonal variability in this area as a consequence of intra- and interpopulation gene flow. We also hypothesize that stands will consist of a mosaic of clones due to dispersal of rhizomes in connection with the harvest.

In a recent phylogeographic study of Phragmites, based on 238 collections spanning most of the vast distribution area, Lambertini et al. (2006) identified a large, fairly well supported, but poorly resolved "core group" within P. australis. Most European clones, including the ones from the Po Plain, belong to this group. The aims of the present study were (i) to assess the genetic diversity within and between $P$. australis populations in the Po Plain area and relate the diversity to wetland size, age and degree of human impact, and (ii) to compare the variation patterns in the Po Plain with geographically distant populations.

\section{Materials and methods}

\subsection{Genetic variation at the population scale}

Eight $P$. australis populations were sampled in the Po Plain, each representing a distinct wetland differing in size, age as well as past and present uses (Table 1). The geographic distance between the two most distant populations is $25 \mathrm{~km}$. In each wetland a total of 15 specimens (shoots) were collected from 10 to $15 P$. australis-dominated patches of vegetation, visibly separated from other such patches. In seven out of eight populations, two or three individuals were collected in at least one patch. The random amplified polymorphic DNA (RAPD) technique was used to identify genotypes and detect the presence of individual clones in populations. Four to seven different clones from each population, as identified by the RAPD analyses, were subsequently amplified for fragments length polymorphism (AFLP). In the Bentivoglia population, which appeared to be monoclonal based on RAPDs, two additional specimens were collected at a distance $>100 \mathrm{~m}$ from the previously sampled patches and AFLP fingerprinted in order to get an idea of the limits of this apparently very extensive clone. In total 46 clones from eight Po Plain populations were analysed by AFLP.

Information about the history and management of the wetlands was acquired from owners and employees of the wetlands and from "Bonifica Renana", the board in charge of water regulation and distribution in the Po Plain area.

\subsection{Genetic variation at the regional scale}

The genetic variation pattern found among Po Plain populations was compared with that of the mixed cytotype population of Lake Razim in the Danube Delta, Romania (Clevering and Lissner, 1999). The eleven samples from Lake Razim have different ploidy levels $(4 x, 6 x, 8 x$ and $12 x)$ and some of the specimens are known to be very closely related, as they originated from seeds of the same inflorescence in the greenhouses of the Netherlands Institute of Ecology in Heteren (Clevering, personal communication, 1999). Specimens 654RO and 655RO are from the same inflorescence, and 658RO, 659RO and 660RO from a panicle of another clone (Table 2). The mother panicles were collected along a $500 \mathrm{~m}$ transect on the land-side of the shore of Lake Razim (Clevering, 1999).

\subsection{Genetic variation at a continental scale}

The genetic distances of the Po Plain clones to increasingly more distant $P$. australis clones were evaluated by comparison with clones from Europe and adjacent parts of Africa and Asia. All belong in the P. australis "core group" retrieved in the phylogeographic study by Lambertini et al. (2006), based on the same AFLP markers. The R Package version $\mathrm{R} 3.02$ (Legendre and Vaudor, 1991) was used to calculate distances of the European clones to the Boscosa wetland of the Po Plain. The European clones were divided into five groups according to their geographical distance from the Po Plain (Table 2). Group 1 included clones at a $\mathrm{km}$ range between 25 and $500 \mathrm{~km}$, group 2 clones $500-1000 \mathrm{~km}$ away, group 3 clones $1000-1500 \mathrm{~km}$ away, and group 4 clones from 1500 to $2000 \mathrm{~km}$ distance. Group 5 included clones more than $2000 \mathrm{~km}$ away (maximum $2530 \mathrm{~km}$ ). For each group, minimum, maximum and average genetic distances with Po Plain clones were calculated.

\subsection{RAPD}

Genomic DNA was extracted from dry leaves with $2 \times$ CTAB buffer (Rogers and Bendich, 1985) and Proteinase K. 
Table 1

Po Plain wetlands from which Phragmites australis populations were sampled

\begin{tabular}{|c|c|c|c|c|c|c|c|c|}
\hline Wetland & GPS coordin & & Size (ha) & Age & Previous management & Current & Hydrographic & Inlet water \\
\hline Bentivoglia & $443104 \mathrm{~N}$ & $114205 \mathrm{E}$ & 86 & $\begin{array}{l}\text { Known since } \\
\text { early } 1900\end{array}$ & $\begin{array}{l}\text { Water reserve for } \\
\text { ricefields and used } \\
\text { later for hunting } \\
\text { and fishing activity }\end{array}$ & Hunting & Canale Medicina & $\begin{array}{l}{ }^{\mathrm{a} C} \text { Canale Medicina } \\
+ \text { Po River }\end{array}$ \\
\hline Boschetti & $443714 \mathrm{~N}$ & $114300 \mathrm{E}$ & 7 & 1967 & Water reserve for fields & Hunting & Scolo Durazzo & ${ }^{\mathrm{b}}$ Precipitation \\
\hline Boscosa & $443327 \mathrm{~N}$ & $113744 \mathrm{E}$ & 88 & $\begin{array}{l}\text { Known since } \\
\text { early } 1900\end{array}$ & $\begin{array}{l}\text { Hunting and fishing } \\
\text { activity. Enlarged } \\
\text { in } 1992\end{array}$ & Hunting & Po River & ${ }^{\mathrm{c}}$ Po River \\
\hline Comune & $444300 \mathrm{~N}$ & $113160 \mathrm{E}$ & 140 & $\begin{array}{l}\text { Known since } \\
\text { early } 1900\end{array}$ & $\begin{array}{l}\text { Water reserve } \\
\text { for ricefields }\end{array}$ & Hunting & Canale Navile & $\begin{array}{l}{ }^{\mathrm{d}} \text { Canale Navile } \\
+ \text { Po River }\end{array}$ \\
\hline Ercolana & $444124 \mathrm{~N}$ & $113005 \mathrm{E}$ & 50 & 1993 & Crops & Hunting & Canale Navile & $\begin{array}{l}{ }^{\mathrm{d}} \text { Canale Navile } \\
+ \text { Po River }\end{array}$ \\
\hline Fracassata & $443113 \mathrm{~N}$ & $113848 \mathrm{E}$ & 33 & $\begin{array}{l}\text { Known since } \\
\text { early } 1900\end{array}$ & $\begin{array}{l}\text { River levee and } \\
\text { water reserve } \\
\text { for ricefields }\end{array}$ & Hunting & Canale Medicina & $\begin{array}{l}{ }^{\mathrm{a} C a n a l e ~ M e d i c i n a ~} \\
+ \text { Po River }\end{array}$ \\
\hline Quadrone & $443104 \mathrm{~N}$ & $114205 \mathrm{E}$ & 37 & $\begin{array}{l}\text { Known since } \\
\text { early } 1900\end{array}$ & $\begin{array}{l}\text { River levee and } \\
\text { water reserve } \\
\text { for ricefields }\end{array}$ & $\begin{array}{l}\text { Natural Reserve } \\
\text { since } 1997\end{array}$ & Canale Medicina & $\begin{array}{l}{ }^{\mathrm{a}} \text { Canale Medicina } \\
+ \text { Po River }\end{array}$ \\
\hline Tombe & $444158 \mathrm{~N}$ & $112829 \mathrm{E}$ & 55 & 1975 & $\begin{array}{l}\text { Ricefield till } 1950 . \\
\text { Crops to } 1975 . \\
\text { Enlarged in } 1992\end{array}$ & Hunting & Canale Navile & $\begin{array}{l}{ }^{\mathrm{d}} \text { Canale Navile } \\
+ \text { Po River }\end{array}$ \\
\hline
\end{tabular}

${ }^{\text {a }}$ Quadrone, Bentivoglia and Fracassata wetlands are in the basin of Canale Medicina and are supplied by Medicina water course during the winter. During the summer they receive water from Po river.

${ }^{\mathrm{b}}$ Boschetti is supplied only by precipitation and is subject to occasional draught during the summer.

c Boscosa is supplied by Po river all year.

${ }^{\mathrm{d}}$ Comune, Tombe and Ercolana wetlands are located in the basin of Canale Navile and are supplied by Canale Navile during the winter. During summer the wetlands receive water from Po river.

DNA was isolated with chloroform/isoamylalcohol (24:1), precipitated with isopropanol, washed with $70 \%$ ethanol and resuspended in $1 \times$ TE buffer. DNA concentration was measured with a spectrophotometer at $260 \mathrm{~nm}$. DNA was diluted to a final concentration of $25 \mathrm{ng} \mu \mathrm{L}^{-1}$.

PCR was performed as described by Koppitz et al. (1997), with some modifications. Two primers were used for amplification, and the procedure was repeated several times on a subset of samples to ensure reproducibility. For primer M13 (5'-GAGGGTGGCGGTTCT-3'), $2 \mu \mathrm{L}$ of DNA solution was added to $25.5 \mu \mathrm{L}$ sterile distilled water, $5 \mu \mathrm{L} 10 \times$ polymerase buffer, $8 \mu \mathrm{L}$ dNTP $(1.25 \mathrm{mM}), 3 \mu \mathrm{L} \mathrm{Mg}$ acetate (3 mM), $6 \mu \mathrm{L}$ M13 primer $\left(10 \mathrm{ng} \mu \mathrm{L}^{-1}\right)$, and $0.5 \mu \mathrm{L}$ Taq ( 5 units $\mu \mathrm{L}^{-1}$ ). The PCR amplification reaction was performed in a MJ Research-Peltier Thermal Cycler PTC-200 programmed for 42 cycles of $20 \mathrm{~s}$ at $93{ }^{\circ} \mathrm{C}, 60 \mathrm{~s}$ at $50{ }^{\circ} \mathrm{C}, 40 \mathrm{~s}$ at $72{ }^{\circ} \mathrm{C}$, followed by a final termination step of 6 min at $72{ }^{\circ} \mathrm{C}$. For primer GACA (5'-GACAGACAGACAGACA-3)' $3 \mu \mathrm{L}$ of DNA solution was added to $16 \mu \mathrm{L}$ sterile distilled water, $5 \mu \mathrm{L}$ $10 \times$ polymerase buffer, $8 \mu \mathrm{L}$ dNTP $(1.25 \mathrm{mM}), 1.5 \mu \mathrm{L} \mathrm{Mg}$ acetate $(3 \mathrm{mM}), 16 \mu \mathrm{L}$ GACA primer $\left(10 \mathrm{ng} \mu \mathrm{L}^{-1}\right)$, and $0.5 \mu \mathrm{L}$ Taq ( 5 units $\mu \mathrm{L}^{-1}$ ). The PCR amplification reaction was performed with an initial step of $3 \mathrm{~min}$ at $94{ }^{\circ} \mathrm{C}$, then 40 repeats of $30 \mathrm{~s}$ at $93{ }^{\circ} \mathrm{C}, 60 \mathrm{~s}$ at $50{ }^{\circ} \mathrm{C}, 40 \mathrm{~s}$ at $72{ }^{\circ} \mathrm{C}$, followed by a final termination step of $6 \mathrm{~min}$ at $72{ }^{\circ} \mathrm{C}$. Amplified products were separated on $1.4 \%$ agarose gels in $1 \times \mathrm{TAE}$ buffer, which included two lanes of $100 \mathrm{bp}$ ladder plus (MBI, Fermenta).
One gel was run for each primer and for each of the eight Po Plain populations. The two primers, M13 and GACA, detected a total of 37 RAPD fragments (respectively 18 and 19 fragments) that were scored visually by means of Cross Checker version 2.91 software (Buntjer, 2000).

\section{5. $A F L P$}

The protocols for DNA extraction, PCR reaction and electrophoresis are described in Lambertini et al. (2006). Three primer combinations E-ACTcy (5'-AGACTGCGTACCAATTCACT- $\left.3^{\prime}\right)+$ M-CTT (5'-GATGAGTCCTGAGTAACTT- $\left.3^{\prime}\right)$, E-CAGcy (5'-GACTGCGTACCAATTCCAG- $\left.3^{\prime}\right)+$ M-ATG (5'-GATGAGTCCTGAGTAACAG- $\left.3^{\prime}\right)$ and E-CGTcy (5'-GACTGCGTACCAATTCCGT-3') + M-CAG (5'-GATGAGTCCTGAGTAACAG- $3^{\prime}$ ) were used. In total 128 AFLP polymorphic fragments were scored.

\subsection{Data analysis}

The genetic diversity within and among Po Plain and Razim populations was evaluated using Popgene ver. 1.32 (Yeh et al., 1997) to calculate Nei's gene diversity $(h)$ (Nei, 1973), Shannon's information index (I) (Lewontin, 1972) and the number and percentage of polymorphic fragments (AFLP) within and among populations. For the Po Plain populations these genetic diversity parameters were related to the size and age of the wetlands in a multiple regression analysis 
Table 2

Populations of Phragmites australis core group (Lambertini et al., 2006) within a range of $2500 \mathrm{~km}$ from Po Plain

\begin{tabular}{|c|c|c|c|c|}
\hline P. australis populations & $\begin{array}{l}\text { No. of samples } \\
\text { per population }\end{array}$ & State & Locality & $\begin{array}{l}\mathrm{km} \text { from } \\
\text { Boscosa }\end{array}$ \\
\hline \multicolumn{5}{|l|}{ (1) $25-500 \mathrm{~km}$ from Po Plain } \\
\hline $75 \mathrm{IT}$ & 1 & Italy & Gorgona Island & 186 \\
\hline $207 \mathrm{IT}$ & 1 & Italy & Albano S. Alessandro, Bergamo & 191 \\
\hline 79SL, 170SL & 2 & Slovenia & Lake Cerkniško & 270 \\
\hline 171SL, 172SL & 2 & Slovenia & Ljubljana & 280 \\
\hline 64DE & 1 & Germany & Chiemsee & 374 \\
\hline $620 \mathrm{CZ}$ & 1 & Czech Republic & Rozmberk & 500 \\
\hline \multicolumn{5}{|l|}{ (2) $500-1000 \mathrm{~km}$ from Po Plain } \\
\hline 77HU, 663HU, 664HU, 668HU & 4 & Hungary & Lake Ferto & 537 \\
\hline 70FR & 1 & France & Campignol, Narbonne & 707 \\
\hline 640DE, 641DE & 2 & Germany & Lusatia mining area, Lake Plessa & 778 \\
\hline 639DE & 1 & Germany & Lusatia mining area, Lake Schlabendorf & 824 \\
\hline $300 \mathrm{ES}$ & 1 & Spain & Mallorca, Alcudia & 872 \\
\hline $67 \mathrm{BE}, 146 \mathrm{BE}$ & 2 & Belgium & Schelde & 914 \\
\hline $163 \mathrm{NL}$ & 1 & Holland & Verdronken Land van Saeftinghe & 935 \\
\hline $78 \mathrm{PL}$ & 1 & Poland & Krakow & 946 \\
\hline $52 \mathrm{ES}$ & 1 & Spain & el Garxal (Ebro) & 998 \\
\hline \multicolumn{5}{|l|}{ (3) $1000-1500 \mathrm{~km}$ from Po Plain } \\
\hline 66NL, 602NL & 2 & Holland & Slotermeer & 1002 \\
\hline 72ES, 74ES, 95ES & 3 & Spain & Gallocanta & 1063 \\
\hline 209GB & 1 & Great Britain & Thamesmead & 1150 \\
\hline $174 \mathrm{TN}$ & 1 & Tunisia & Chenini (Gabés) & 1195 \\
\hline 609DK, 610DK & 2 & Denmark & Vejlerne & 1249 \\
\hline 49DK & 1 & Denmark & Norsminde Fjord & 1278 \\
\hline $670 \mathrm{~GB}$ & 1 & Great Britain & Blacktoft Sands & 1288 \\
\hline $50 \mathrm{DK}$ & 1 & Denmark & Knebel Vig & 1299 \\
\hline 81RO, 84RO, 624RO, 625RO & 4 & Romania & Lake Obretinu-Mare/Oborny & 1308 \\
\hline $\begin{array}{l}\text { 643RO, 650RO, 651RO, 652RO, } \\
654 \mathrm{RO}, 655 \mathrm{RO}, 656 \mathrm{RO}, 657 \mathrm{RO} \\
658 \mathrm{RO}, 659 \mathrm{RO}, 66 \mathrm{ORO}\end{array}$ & 11 & Romania & Lake Razim & 1366 \\
\hline $85 \mathrm{LI}$ & 1 & Lithuania & Silute & 1388 \\
\hline $57 \mathrm{GR}$ & 1 & Greece & Creete & 1495 \\
\hline \multicolumn{5}{|l|}{ (4) $1500-2000 \mathrm{~km}$ from Po Plain } \\
\hline $615 \mathrm{SE}$ & 1 & Sweden & Tåkern & 1562 \\
\hline $58 \mathrm{IE}$ & 1 & Ireland & Kilcock & 1574 \\
\hline $165 \mathrm{IE}$ & 1 & Ireland & Hazelhatch & 1594 \\
\hline 164IE & 1 & Ireland & Lake Ree & 1615 \\
\hline $83 \mathrm{EE}$ & 1 & Estonia & Lake Vortsjarv & 1807 \\
\hline 54FI, 160FI & 2 & Finland & Åland & 1816 \\
\hline $217 \mathrm{FI}$ & 1 & Finland & Raisionlahti, Turku & 1903 \\
\hline 159EE & 1 & Estonia & Lake Peipsi & 1942 \\
\hline \multicolumn{5}{|l|}{ (5) $2000-2530 \mathrm{~km}$ from Po Plain } \\
\hline 169RU & 1 & Russia & St. Petersbourg & 2110 \\
\hline 141SE & 1 & Sweden & Luleå & 2423 \\
\hline H13IL & 1 & Israel & Lake Huleh, Hulata & 2426 \\
\hline 637SE & 1 & Sweden & Gammelstaden & 2426 \\
\hline 90IL, 91IL & 2 & Israel & Yerokham, Negev Highlands & 2528 \\
\hline
\end{tabular}

Populations are ordered according to increasing geographical distance from Boscosa wetland (Po Plain) and divided in five kilometric ranges.

(StatGraphics Plus 4.1, Manugistics Inc., Rockville, MD, USA). Populations that were known since the early 1900s were assigned an age of 100 years.

The genetic structure was evaluated using AMOVA based on the distance matrix of pairwise differences with Arlequin ver. 2.000 (Schneider et al., 2000). AMOVA was calculated within and among the eight Po Plain populations, within and among all nine populations studied, including Razim, and within and among two groups, one consisting of the eight Po Plain populations and the other of the Razim population. The fixation index $\left(F_{\mathrm{ST}}\right)$, calculated with the $\theta$ algorithm of Weir and Cockerham (1984), indicates the extent of genetic differentiation among populations (Michalakis and Excoffier, 1996). It was calculated also for each of the AFLP fragments amplified with the aim of differentiating the Po Plain populations from the Razim population, based on the presence/absence of exclusive AFLP markers or with high $F_{\mathrm{ST}}$ value. The significance of the fixation indices associated with the different levels of genetic 
Table 3

Genetic diversity of Phragmites australis in Po Plain and Razim populations

\begin{tabular}{|c|c|c|c|c|c|}
\hline Populations & $\begin{array}{l}\text { No. of clones fingerprinted } \\
\text { by AFLP }\end{array}$ & $\begin{array}{l}\text { Nei’s gene } \\
\text { diversity }(h)\end{array}$ & $\begin{array}{l}\text { Shannon's information } \\
\text { index }(I)\end{array}$ & $\begin{array}{l}\text { No. of polymorphic } \\
\text { fragments }\end{array}$ & $\begin{array}{l}\text { Polymorphic } \\
\text { fragments }(\%)\end{array}$ \\
\hline \multicolumn{6}{|l|}{ Within populations } \\
\hline Bentivoglia & 3 & 0.148 & 0.213 & 44 & 34.4 \\
\hline Boschetti & 5 & 0.071 & 0.107 & 25 & 19.5 \\
\hline Boscosa & 4 & 0.091 & 0.134 & 29 & 22.7 \\
\hline Comune & 7 & 0.138 & 0.211 & 52 & 40.6 \\
\hline Ercolana & 7 & 0.133 & 0.202 & 50 & 39.1 \\
\hline Fracassata & 5 & 0.081 & 0.120 & 27 & 21.1 \\
\hline Quadrone & 6 & 0.178 & 0.261 & 57 & 44.5 \\
\hline Tombe & 6 & 0.139 & 0.208 & 48 & 37.5 \\
\hline Razim (RO) & 11 & 0.157 & 0.241 & 62 & 48.4 \\
\hline \multicolumn{6}{|l|}{ Among populations } \\
\hline Po Plain & 43 & 0.169 & 0.272 & 93 & 72.7 \\
\hline Po Plain and Razim & 54 & 0.175 & 0.283 & 99 & 77.3 \\
\hline
\end{tabular}

structure was tested using non-parametric permutation procedures (1000 permutations) (Excoffier et al., 1992). The genetic structure of the investigated populations was compared with that reported in other studies by calculating the genetic structure among populations with the $G_{\mathrm{ST}}$ algorithm of Nei (1987) using Popgene ver. 1.32.

The correlation between population pairwise $F_{\text {ST }}$ and geographic pairwise distances was tested in a Mantel test (Mantel, 1967; Smouse et al., 1986) using Arlequin ver. 2 based on 1000 permutations.

Neighbour-joining analysis (NJ), using PAUP* 4.0b10 (Phylogenetic Analysis Using Parsimony; Swofford, 1998) was carried out to evaluate the relationships among the Po Plain clones. The analysis was based on restriction-site distances (Nei and Li, 1979) and a P. vallatoria (Plunk. ex L.) Veldk. specimen was included as outgroup. The data were subject to jack-knife analysis with $37 \%$ character deletion (Farris et al., 1996), "emulate jac resampling" and 1000 replicates. Pairwise genetic distances (Nei and Li, 1979) between clones were also calculated with PAUP.

Differences in pairwise genetic distances between the increasingly geographically distant groups of $P$. australis clones from the Po Plain were tested in an ANOVA with Statgraphics Plus 4.1. Bonferroni multiple range test was applied at the $99 \%$ confidence level. Significance was also tested with a non-parametric Kruskal-Wallis test at the $95 \%$ confidence level with the same program.

\section{Results}

\subsection{Genetic diversity}

Among the 15 specimens analysed in each Po Plain population, the number of distinct genotypes ranged from 12 to 15 , except for the Bentivoglia population, which was found to be monoclonal (excluding the two clones, from patches $\mathrm{M}$ and $\mathrm{N}$, subsequently collected at the edge of the area close to the inlet river). In the other populations at least one genotype was found in each patch. In Tombe and Quadrone more than one clone was found in the same patch in two cases. No genotype was present in more than one population.

On the intrapopulation level, Nei's gene diversity $(h)$ of the Po Plain populations ranged between 0.07 and 0.18 , Shannon's information index $(I)$ ranged between 0.11 and 0.26 , the number of polymorphic fragments ranged between 25 and 57, and the percentage of polymorphic fragments ranged between 19.5 and $44.5 \%$ (Table 3). No correlation was found between these genetic parameters and size or age of the wetlands in the Po Plain. The genetic diversity of the Romanian Razim population was within the range of the Po Plain population ( $h=0.16 ; I=0.24$ ) in spite of the different ploidy levels and the higher number of polymorphic fragments.

On the interpopulation level, the genetic diversity and percentage of polymorphic fragments was higher than that observed within populations. Nei's gene diversity (0.17) was within the range seen within populations. When the Razim population was included in the interpopulation analysis, all diversity measures increased (Table 3 ).

\subsection{Genetic structure}

Most of the genetic variation in the Po Plain populations occurs within $(85.3 \%)$ rather than among $(14.7 \%)$ populations (Table 4$)$. The fixation index $\left(F_{\mathrm{ST}}\right)$ among the Po Plain populations $(0.15)$ indicates that there is a certain degree of genetic subdivision among the eight populations, but by including the Romanian population in the analyses the $F_{\mathrm{ST}}$ increased only slightly. When testing the Po Plain populations against the Romanian population, the fixation index among groups of populations decreased to 0.04 . Pairwise $F_{\mathrm{ST}}$ in the Po Plain populations ranged from 0.02 to 0.32 . The Boschetti population showed, with one exception, the highest pairwise $F_{\text {ST }}$ with the other Po Plain populations indicating some genetic separation of this population from the other Po Plain populations. Pairwise $F_{\text {ST }}$ between the Romanian population and the eight Po Plain populations ranged between 0.10 and 0.21 and the Romanian population was found to be genetically less distinct than Boschetti from the other Po Plain populations. 
Table 4

Phragmites australis: results of AMOVA and $G_{\mathrm{ST}}$

\begin{tabular}{|c|c|c|c|c|}
\hline Source of variation & df & Sum of squares & Variance components & $\%$ of variation \\
\hline \multicolumn{5}{|l|}{ (A) Po Plain populations } \\
\hline Among populations & 7 & 129.74 & $1.605 \mathrm{Va}$ & 14.7 \\
\hline Within populations & 38 & 354.92 & $9.340 \mathrm{Vb}$ & 85.3 \\
\hline Total & 45 & 484.65 & 10.945 & \\
\hline \multicolumn{5}{|l|}{ Fixation index } \\
\hline$F_{\mathrm{ST}}$ & 0.147 & & & \\
\hline$P\left(\mathrm{Va}\right.$ and $\left.F_{\mathrm{ST}}\right)$ & $<0.01$ & & & \\
\hline$G_{\mathrm{ST}}$ & 0.2786 & & & \\
\hline \multicolumn{5}{|c|}{ (B) Po Plain populations + Razim population (without grouping) } \\
\hline Among populations & 8 & 162.24 & $1.696 \mathrm{Va}$ & 14.9 \\
\hline Within populations & 48 & 463.46 & $9.655 \mathrm{Vb}$ & 85.01 \\
\hline Total & 56 & 625.70 & 11.352 & \\
\hline \multicolumn{5}{|l|}{ Fixation index } \\
\hline$F_{\mathrm{ST}}$ & 0.149 & & & \\
\hline$P\left(\mathrm{Va}\right.$ and $\left.F_{\mathrm{ST}}\right)$ & $<0.01$ & & & \\
\hline$G_{\mathrm{ST}}$ & 0.2741 & & & \\
\hline \multicolumn{5}{|c|}{ (C) Two groups: Po Plain populations and Razim population } \\
\hline Among groups & 1 & 32.50 & $0.412 \mathrm{Va}$ & 3.6 \\
\hline Among populations within groups & 7 & 129.74 & $1.550 \mathrm{Vb}$ & 13.3 \\
\hline Within populations & 48 & 463.46 & $9.655 \mathrm{Vc}$ & 83.1 \\
\hline Total & 56 & 625.70 & 11.618 & \\
\hline \multicolumn{5}{|l|}{ Fixation indexes } \\
\hline$F_{\mathrm{CT}}$ & 0.035 & $P\left(\mathrm{Va}\right.$ and $\left.F_{\mathrm{CT}}\right)>0.05$ & & \\
\hline$F_{\mathrm{SC}}$ & 0.138 & $P\left(\mathrm{Vb}\right.$ and $\left.F_{\mathrm{SC}}\right)<0.01$ & & \\
\hline$F_{\mathrm{ST}}$ & 0.169 & $P\left(\mathrm{Vc}\right.$ and $\left.F_{\mathrm{ST}}\right)<0.01$ & & \\
\hline$G_{\mathrm{ST}}$ & 0.0795 & & & \\
\hline
\end{tabular}

(A) Within and among Po Plain populations; (B) within and among nine populations (Po Plain and Razim populations); (C) within and among two groups: Po Plain populations (group 1) and Razim population (group 2). $P$ values are based on 1023 permutations.

No correlation was detected between the $F_{\mathrm{ST}}$ value and the geographic distance between populations.

None of the detected AFLP fragments were unique for individual populations or groups of populations. Fragments that initially appeared exclusive to the Bentivoglia population were found to be present also in Romania, and fragments that were exclusive to octoploids and dodecaploids of the Razim population were found also in the Po Plain clones.

\subsection{Genetic interrelationships at the population scale}

The genetic relationships among the Po Plain clones can be seen from the NJ tree in Fig. 1. Only a few groups were well supported (jack-knife values from 96 to 100\%) and these were all small: two pairs of clones from Comune, one pair of clones from Boschetti, one pair of clones from Tombe, and one pair of clones from Quadrone. The remaining supported groups were small (two to four clones) with weaker support (jack-knife values from 53 to 77), except for a large group comprising 36 Po Plain clones representing virtually all wetlands, drainage areas and irrigation regimes.

To understand the nature of the relationships among clones of the Po Plain populations, pairwise genetic distances between clones were calculated. Genetic distances among clones of different populations, tentatively considered as unrelated, range between 0.011 and 0.072 . Shorter distances were found inside the populations (Table 5A). The genetic similarities between related clones group around two levels of variation. Very short distances were found between clones of the same patch at Quadrone (0.002) and at Tombe (0.004) and between clones of two neighbouring patches at Comune (0.003) and Boschetti (0.004). The pairs of clones from Quadrone, Tombe and Comune differed in two DNA fragments, and the two clones from Boschetti differed in three fragments. Genetic distances, of the same level as between unrelated clones, were found within the population of Comune (0.010). The two clones differed in six DNA fragments. The clones of different populations that were considered as unrelated and with a genetic distance between 0.011 and 0.072 differed in 7-45 DNA fragments. The Romanian population generally showed a similar genetic distance range as the Po Plain populations (Table 5A). The sibling specimens 654RO and 655RO had a genetic distance of 0.027 and differed in 21 DNA fragments, while the siblings $658 \mathrm{RO}, 659 \mathrm{RO}$ and $660 \mathrm{RO}$ had genetic distances between 0.020 and 0.029 and differed in 16-21 DNA fragments. 


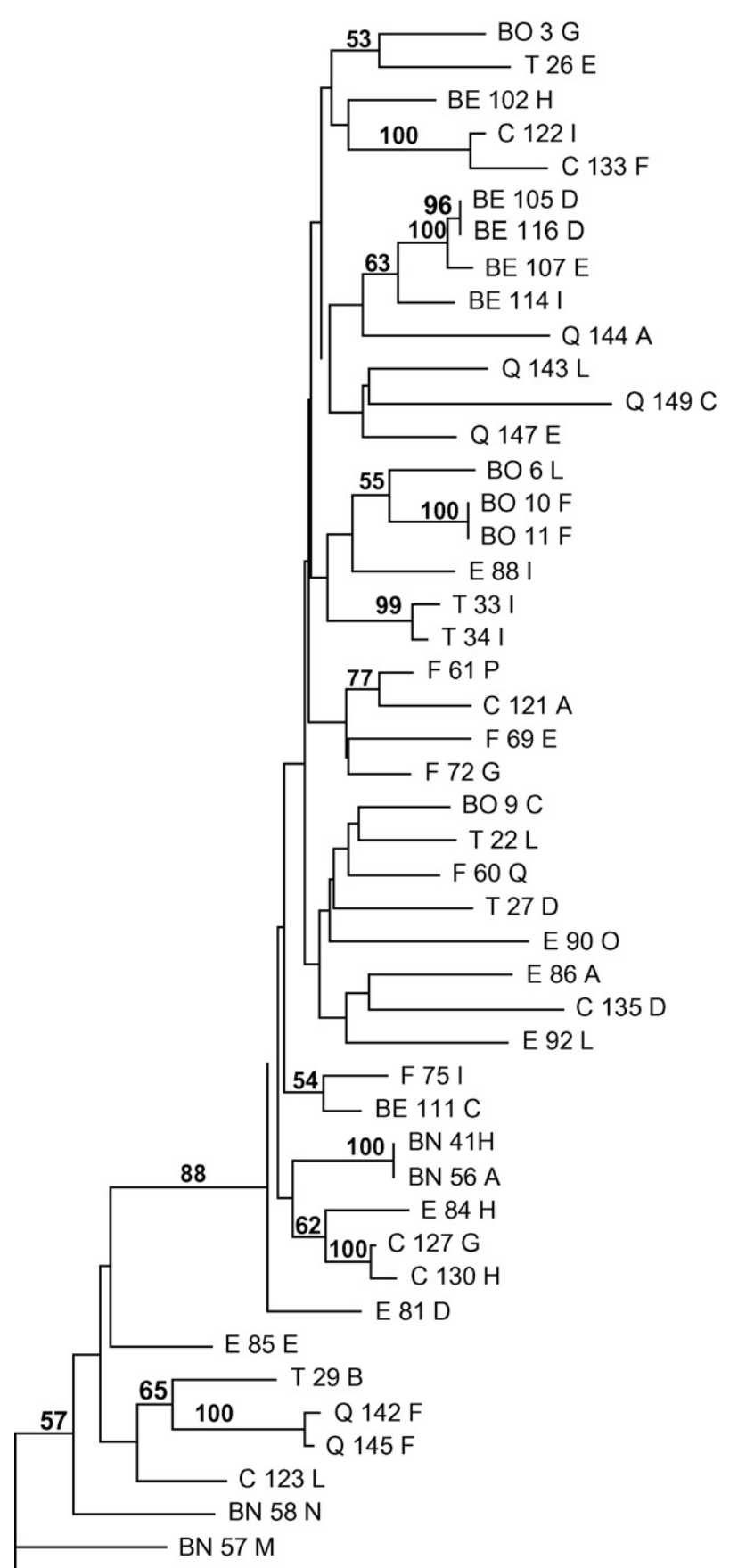

P. vallatoria $59 \mathrm{TH}$

- 0.005 Genetic distance (Nei and Li, 1979)

Fig. 1. Neighbour-joining tree of Po Plain Phragmites australis clones. Terminals are labelled with population abbreviation (BE: Boschetti, BN: Bentivoglia, BO: Boscosa, C: Comune, E: Ercolana, F: Fracassata, Q: Quadrone, T: Tombe), sample number and patch letter. Consecutive patch letters indicate neighbouring patches. When the same patch letter is associated with different sample numbers of a single population, more than one shoot was collected in that patch. BN58N and BN57M are the clones collected from Bentivoglia after RAPD analysis, close to the inlet river.

\subsection{Genetic relationships at a continental scale}

Irrespective of the geographical scale considered, the Po Plain clones showed a wide range of variation in genetic distance to other clones (Table 5B). Ranges of genetic distance largely overlapped between geographical distance ranges considered. As the Po Plain clones were compared to geographically successively more distant clones, the maximum genetic distances between these and the Po Plain clones remained roughly the same. In contrast, minimum genetic distance did show a considerable increase as the range of geographical distances exceeded $2000 \mathrm{~km}$. Only in the $>2000 \mathrm{~km}$ range did minimum and maximum genetic distances correspond to the shortest and longest geographical distances. 
Table 5

Range of genetic distance between Phragmites australis populations (min., max., average and standard deviation)

\begin{tabular}{|c|c|c|c|c|c|c|c|c|c|c|c|c|}
\hline $\begin{array}{l}\text { Geographic distance } \\
\text { range }\end{array}$ & $\begin{array}{l}\text { No. pairwise } \\
\text { calculations }\end{array}$ & $\begin{array}{l}\text { Min. genetic } \\
\text { distance }\end{array}$ & $\begin{array}{l}\text { Clones with } \\
\text { min. genetic } \\
\text { distance }\end{array}$ & & $\begin{array}{l}\text { Km distance } \\
\text { between clones }\end{array}$ & $\begin{array}{l}\text { Max genetic } \\
\text { distance }\end{array}$ & $\begin{array}{l}\text { Clones with } \\
\text { max. genetic } \\
\text { distance }\end{array}$ & & $\begin{array}{l}\text { Km distance } \\
\text { between } \\
\text { clones }\end{array}$ & $\begin{array}{l}\text { Average } \\
\text { genetic } \\
\text { distance }\end{array}$ & $\begin{array}{l}\text { Standard } \\
\text { deviation }\end{array}$ & ANOVA \\
\hline \multicolumn{13}{|l|}{ (A) Within population } \\
\hline Bentivoglia & 3 & 0.030 & BN57M-IT & BN58N-IT & $<1$ & 0.049 & BN56A-IT & BN57M-IT & $<1$ & 0.041 & 0.010 & \\
\hline Boschetti & 10 & 0.004 & BE105E-IT & BE107D-IT & $<1$ & 0.024 & BE107E-IT & BE111C-IT & $<1$ & 0.018 & 0.007 & \\
\hline Boscosa & 6 & 0.016 & BO6L-IT & BO10F-IT & $<1$ & 0.033 & BO9C-IT & BO10F-IT & $<1$ & 0.026 & 0.007 & \\
\hline Comune & 21 & 0.003 & C127G-IT & C130H-IT & $<1$ & 0.059 & C123L-IT & C133F-IT & $<1$ & 0.034 & 0.014 & \\
\hline Ercolana & 21 & 0.017 & E81D-IT & E84H-IT & $<1$ & 0.043 & E85E-IT & E92L-IT & $<1$ & 0.032 & 0.008 & \\
\hline Fracassata & 10 & 0.015 & F61P-IT & F72G-IT & $<1$ & 0.030 & F60Q-IT & F69E-IT & $<1$ & 0.020 & 0.006 & \\
\hline Quadrone & 15 & 0.002 & Q142F-IT & Q145F-IT & $<1$ & 0.064 & Q142F-IT & Q144A-IT & $<1$ & 0.042 & 0.017 & \\
\hline Tombe & 15 & 0.004 & T33I-IT & T34I-IT & $<1$ & 0.048 & T27D-IT & T29B-IT & $<1$ & 0.033 & 0.011 & \\
\hline Razim (RO) & 56 & 0.019 & $650 \mathrm{RO}$ & $654 \mathrm{RO}$ & & 0.047 & $658 \mathrm{RO}$ & $643 \mathrm{RO}$ & & 0.032 & 0.007 & \\
\hline \multicolumn{13}{|c|}{ (B) $\mathrm{km}$ range from Po Plain } \\
\hline $0-25$ & 899 & 0.011 & BE111C-IT & F75I-IT & 9 & 0.072 & T29B-IT & IT35C & 4 & 0.035 & 0.012 & $\mathrm{a}$ \\
\hline $25-500$ & 343 & 0.016 & F72G-1T & $620 \mathrm{CZ}$ & 500 & 0.064 & BN57M-IT & $171 \mathrm{SL}$ & 280 & 0.035 & 0.009 & a \\
\hline $500-1000$ & 635 & 0.014 & BE111C-IT & $146 \mathrm{BE}$ & 914 & 0.068 & BN57M-IT & $70 \mathrm{FR}$ & 707 & 0.038 & 0.010 & $\mathrm{~b}$ \\
\hline $1000-1500$ & 1247 & 0.013 & F75I-IT & 670GB & 1288 & 0.067 & BN58N-IT & $656 \mathrm{RO}$ & 1366 & 0.038 & 0.010 & $\mathrm{~b}$ \\
\hline $1500-2000$ & 387 & 0.019 & BO10F-IT & 164IE & 1615 & 0.079 & BN57M-IT & $615 \mathrm{SE}$ & 1562 & 0.042 & 0.010 & $\mathrm{c}$ \\
\hline $2000-2530$ & 257 & 0.044 & F72G-1T & $169 \mathrm{RU}$ & 2110 & 0.074 & BN57M-IT & 90IL & 2530 & 0.044 & 0.011 & $\mathrm{c}$ \\
\hline
\end{tabular}

(A) Within Po Plain and Razim populations. Clones are labelled with population abbreviation (BE: Boschetti, BN: Bentivoglia, BO: Boscosa, C: Comune, E: Ercolana, F: Fracassata, Q: Quadrone, T: Tombe), sample number, patch letter and country acronym; (B) between Po Plain clones and geographically distant clones. Clones are labelled with sample reference and country acronym. ANOVA results are based on Bonferroni multiple range test at the $99 \%$ confidence level. 
The average genetic distance increased slightly with increasing geographical distance. Standard deviation remained nearly constant between geographical ranges. Analysis of variance revealed highly significant differences in the genetic distances under and over $500 \mathrm{~km}$, and under and over $1500 \mathrm{~km}$ of range.

\section{Discussion}

\subsection{Genetic diversity}

Seven of the eight $P$. australis populations studied in the Po Plain were polyclonal, but one fairly large wetland ( $86 \mathrm{ha}$ ) at Bentivoglia was found to be monoclonal. This wetland has probably never been drained. The patches from which the specimens were collected are in the oldest part of the wetland, which is managed exclusively for hunting purposes. These patches have been frequently cut, but rhizomes have not been removed in the last 50 years, at least, and presumably never. Two additional clones were found close to the inlet river where disturbance and opportunity for seedling establishment is higher. The low genetic variability in the Bentivoglia population can probably be explained by the rather stable environmental conditions over a long time period, as has also been observed for other monodominant clonal species (Watkinson and Powell, 1993). In the polyclonal populations clonal variability is high, and every $P$. australis patch consists of at least one distinct genotype. In two out of seven cases there were two different genotypes in the same patch. The polyclonal wetlands are comparatively young, often restored from rice fields or other croplands within the last 30 years, and disturbance occurs very frequently. The genotypes found in the eight Po Plain wetlands are exclusive to each $P$. australis population and were not found in other patches.

Within the Po Plain populations Quadrone, a river levee that has been a nature reserve since 1997, has the most diverse population. The management of this wetland is aimed at keeping channels and ponds free of vegetation, allowing high flow of water at any time of the year. The expansion of $P$. australis stands is therefore strictly controlled. In recent years part of the wetland has been drained, which may have created opportunities for the recruitment and establishment of new clones. Boschetti, on the other hand, is the least genetically diverse population, which is in accordance with its small size and lower level of human disturbance. No correlation however was found between age and/or size of wetland and genetic diversity of the $P$. australis populations, although it should be noted that sample size is small and wetland age in some cases probably underestimated. Hence, it is probably the human impact associated with the management of the wetlands that are of importance for the genetic diversity in the Po Plain populations.

The Romanian Razim population has a genetic diversity at the same level as that of the Po Plain populations. Lake Razim is located in the Danube Delta and has been a UNESCO biosphere reserve since 1999. Regrettably, very little information is available on present and past disturbance in the study area. It is surprising to note that populations so geographically distant and so different in terms of climate and environmental conditions in general as Lake Razim and the Po Plain, have the same extent of genetic diversity. Higher genetic diversity (Nei's gene diversity between 0.08 and 0.30 ) has been found by Guo et al. (2003) in 15 P. australis populations in the Yellow River Delta in China. A diversity-generating factor in the delta is the advancement of the shoreline, which creates suitable habitats for the establishment of $P$. australis clones.

The interspecific variation in the percentage of polymorphic loci (Ps) in plants is largely explained by the breeding systems and seed dispersal mechanisms (Hamrick and Godt, 1996). Mean levels of Ps for outcrossing and wind-dispersed plant species are 62.4, and 62.7 for Poaceae species. Lower Ps levels were observed within the Po Plain population (from 19.5 to 44.5) and the Razim populations (48.4), while higher values were registered on the interpopulation level (72.7 among the Po Plain populations; 77.3 including the Razim population). It is interesting to note how each population contributes a number of different loci (and different genotypes) to the gene pool of $P$. australis in the Po Plain.

\subsection{Genetic structure}

The analysis of molecular variance shows that most of the genetic variation is within populations, i.e. among the clones of each population, which is typical of long-lived, outcrossing and late successional taxa (Nybom and Bartish, 2000). The $F_{\text {ST }}$ values at the interpopulation level are relatively high compared to various plant groups and categories described by Hamrick and Godt (1996). $G_{\mathrm{ST}}$ values are close to the average for Poaceae species $(0.28)$ but higher than the average level of genetic variation among populations of outcrossing and winddispersed plant species (0.10), outcrossing monocots (0.16), outcrossing and widespread plant species $(0.17)$, and perennial outcrossing plant species (0.09). A certain degree of genetic structure seems therefore to be present among the P. australis populations investigated in this study, which seems to have little to do with the geographical distribution of the populations. For comparison, differentiation among populations of another clonal, emergent aquatic plant, Typha latifolia, was one order of magnitude lower $\left(F_{\mathrm{ST}}=0.013\right)$ in populations of different hydrographic basins in the Flanders (Lamote et al., 2005). The least genetically diverse population of Boschetti is also the most genetically isolated population as indicated by the pairwise $F_{\text {ST }}$ among populations. It can be speculated that the genetic isolation is a result of the hydrographic isolation of this wetland from the network of wetlands to which the other investigated populations in the Po Plain belong. Boscosa, which like all other investigated populations in the Po Plain, is supplied by the Po river, also showed relatively high $F_{\mathrm{ST}}$ values with the other populations and, like Boschetti, was not exceptional with respect to the extent of genetic diversity within populations (Table 3). At the regional level the genetic structure observed on the interpopulation level collapsed. Fixation indices decreased radically and geographically very distant populations were found to be genetically very similar, indicating possible gene flow between the populations. This pattern can be explained by 
the lack of gene flow within and between populations of the same gene pool after the "propagation and establishment stage" (Koppitz and Kühl, 2000). With time, the different contingents of genotypes present in each population, and different selection pressure, differentiate populations. The competitive exclusion of clones can affect the genetic diversity by reducing the number of genotypes. This could explain why the least genetically diverse populations are also the most isolated ones. Weak gene flow at the population level was documented also by Guo et al. (2003) in the populations of Yellow River Delta. By contrast, in the clonal species Cirsium arvense (Asteraceae) the amount of population differentiation was similar between founder and established populations indicating that selection acts mostly in the very early stage of succession (Solè et al., 2004). A pattern more similar to that of $P$. australis in the Po Plain in terms of genetic diversity and distribution of genetic variation was found in the riparian perennial Silene tatarica in northern Finland (Tero et al., 2003).

\subsection{Genetic interrelationships at the population scale}

The genetic differences detected among the Po Plain clones show that clones within one population are very different. A few close relationships are suggested by the NJ tree (mostly pairs) and these are characterized by very short genetic distances. The clones showing the shortest genetic distances were collected either from the same patch (Q142F-Q145F and T33I-T34I) or from two neighbouring patches (BE105DBE107E and C127G-C130H) 10 m apart, separated by an open area with short wetland vegetation. The two patches may have been connected by rhizomes. The specimens differ for just two and three AFLP fragments out of 128, have different RAPD patterns and DNA was extracted twice (for RAPD and AFLP analyses). A possible explanation for these minimal genetic differences could be somatic mutations, which are known to occur in several clonal species (Klekowski, 1997), including $P$. australis (Connor et al., 1998). Another possibility which has support from preliminary microsatellites results of crosspollination experiments (Lambertini et al., unpublished), could be self-pollination followed by establishment of selfed seeds.

An interesting case of an intermediate level of difference between a pair of clones within a population is seen at Comune. The two clones (C122I-C133F) were collected in distant and evidently disconnected patches and their genetic distance of 0.010 is of the same order of magnitude as between clones of different Po Plain populations, but in contrast to these, the relationship between the two clones from Comune has $100 \%$ jack-knife support. The genetic distance is more than twice that found in the aforementioned pairs of clones where somatic mutation or self-pollination were suspected. The nature of the relationship remains to be determined, but it could perhaps represent a descent or sibling relationship. The known cases of sibling relationships in the Razim population show, however, greater genetic differences. This may not be so surprising, as the degree of similarity between siblings obviously varies as a function of the genetic similarity between the parents and stochastically through recombination.

\subsection{Genetic relationships at a continental scale}

Samples analysed in the present study were included in an AFLP-based phylogeographic study of the genus Phragmites (Lambertini et al., 2006). Samples from the Po Plain and Razim Lake formed part of a large group within P. australis in which relationships among clones were largely uncertain. This group comprised all European clones belonging to P. australis, along with several clones from other continents. Apart from some minor clusters of Po Plain clones (consisting of pairs of clones with very short genetic distances), most of these appeared to have their closest relatives in other parts of Europe rather than in the same or nearby wetlands. Also Razim Lake sibling clones showed more genetic similarities with clones from other regions or continents than between themselves.

The present study shows that the genetic distances between the Po Plain clones and geographically distant clones increase significantly with clones over $500 \mathrm{~km}$ away. Additional significant increase in genetic distance is observed when clones over $1500 \mathrm{~km}$ were considered. Variation is, however, considerable, and even among clones more than $1500 \mathrm{~km}$ from the Po Plain, some have genetic distances shorter than between neighbouring clones in the Po Plain. This indicates that gene flow does occur within these distance ranges, but with a lower frequency. The "stepwise" increase in genetic distances with increasing geographical distance may indicate the presence of some kind of genetic pattern at a very large geographical scale.

Possible explanations for an apparently continent-wide gene pool would include the possibility of long-distance dispersal by seeds or gene flow by pollen. The reproductive biology of $P$. australis is still not fully resolved (Ishii and Kadono, 2002), but it is clear that pollen can be carried long distances by air. Seeds can be dispersed by air or water (Coops and Van der Velde, 1995) or stick to the feather of migratory birds. New wetlands are often colonized very quickly by $P$. australis, indicating that many seeds are transported either by air or water. Additional indications of the efficiency of the dispersal of $P$. australis are its virtually cosmopolitan distribution, its occurrence in isolated patches of suitable habitat such as oceanic islands (Saltonstall, 2002), and its presence in nearly every lake, pond, river, and marsh in the northern temperate zone. The frequency of such long-distance dispersal and pollination events remains to be determined, but our data suggest that all $P$. australis populations continent wide in Europe are one single meta-population. Deliberate introduction and unintentional dispersal by humans could explain some of the remarkable trans-continental affinities between clones, and could be expected to partly disrupt geographical variation patterns. Nevertheless, we find support for the existence of a weak geographical pattern, but on a very large scale only.

\section{Acknowledgements}

Dr. Heike Koppitz is thanked for instructing in the RAPD technique. Dr. Bodil Ehlers and two anonymous referees are thanked for valuable comments to the manuscript. The study was partly funded by the Danish Natural Science Research Council, project no. 21-02-0479. 


\section{References}

Barrett, S.C.H., Eckert, C.G., Husband, B.C., 1993. Evolutionary processes in aquatic plant populations. Aquat. Bot. 44, 105-145.

Brix, H., 1999. Genetic diversity, ecophysiology and growth dynamics of reed (Phragmites australis). Aquat. Bot. 64, 179-184.

Brix, H., Cizkova, H., 2001. Introduction: Phragmites-dominated wetlands, their functions and sustainable use. Aquat. Bot. 69, 87-88.

Buntjer, J., 2000. Cross checker: computer assisted scoring of genetic AFLP data. In: International Plant and Animal Genome VIII Conference, San Diego, CA, January 9-12, 2000.

Charpentier, A., 2002. Consequences of clonal growth for plant mating. Evol. Ecol. 15, 521-530.

Clevering, O.A., 1999. Between- and within-population differences in Phragmites australis. 1: The effect of nutrients on seedling growth. Oecologia 121, 447-457

Clevering, O.A., Lissner, J., 1999. Taxonomy, chromosome numbers, clonal diversity and population dynamics of Phragmites australis. Aquat. Bot. 64 $185-208$

Connor, H.E., Dawson, M.I., Keating, R.D., Gill, L.S., 1998. Chromosome number in Phragmites australis (Arundineae: Gramineae) in New Zealand. N. Z. J. Bot. 36, 465-469.

Coops, H., Van der Velde, G., 1995. Seed dispersal, germination and seedling growth of six helophyte species in relation to water-level zonation. Freshwater Biol. 34, 13-20.

Eriksson, O., 1997. Clonal life histories and evolution of seed. In: De Kroon, H., Van Groenendael, J. (Eds.), The Ecology and Evolution of Clonal Plants. Backhuys Publication, Leiden, pp. 185-210.

Excoffier, L., Smouse, P., Quattro, J., 1992. Analysis of molecular variance inferred from metric distances among DNA haplotypes: application to human mitochondrial DNA restriction data. Genetics 131, 479-491.

Farris, J.S., Albert, V.A., Källersjö, M., Lipscomb, D., Kluge, A.G., 1996 Parsimony jackknifing outperforms neighbor-joining. Cladistics 12, 99124.

Guo, W., Wang, R., Zhuo, S., Zhang, S., Zhang, Z., 2003. Genetic diversity and clonal structure of Phragmites australis in the Yellow River delta of China. Biochem. Syst. Ecol. 31, 1093-1109.

Hamrick, J.L., Godt, M.J.W., 1996. Effects of life history traits on genetic diversity in plant species. Philos. Trans. R. Soc. Lond. B 351, 1291-1298.

Ishii, J., Kadono, Y., 2002. Factors influencing seed production of Phragmites australis. Aquat. Bot. 72, 129-141.

Klekowski jr., E.J., 1997. Somatic mutation theory of clonality. In: De Kroon, H., Van Groenendael, J. (Eds.), The Ecology and Evolution of Clonal Plants. Backhuys Publication, Leiden, pp. 227-242.

Koppitz, H., Kühl, H., Hesse, K., Kohl, J.G., 1997. Some aspects of the importance of genetic diversity in Phragmites australis (Cav.) Trin. ex Steud. for the development of reed stands. Bot. Acta 110, 217-223.

Koppitz, H., Kühl, H., 2000. To the importance of genetic diversity of Phragmites australis in the development of reed stands. Wetlands Ecol. Manage. 8, 403-414.

Lambertini, C., Gustafsson, M.H.G., Frydenberg, J., Lissner, J., Speranza, M., Brix, H., 2006. A phylogeographic study of the cosmopolitan genus Phragmites (Poaceae) based on AFLPs. Plant Syst. Evol. 258, 161-182.
Lamote, V., De Loose, M., Van Bockstaele, E., Roldán-Ruiz, I., 2005. Evaluation of AFLP markers to reveal genetic diversity in Typha. Aquat. Bot. 83, 296-309.

Legendre, P., Vaudor, A., 1991. The R-package: Multidimensional Analysis, Spatial Analysis. Département des Sciences Biologiques, Université de Montréal.

Lewontin, R.C., 1972. Apportionment of human diversity. Evol. Biol. 6, 381-398.

Mantel, N.A., 1967. The detection of disease clustering and a generalized regression approach. Cancer Res. 27, 209-220.

Michalakis, Y., Excoffier, L., 1996. A generic estimation of population subdivision using distances between alleles with special reference to microsatellite loci. Genetics 142, 1061-1064.

Nei, M., 1973. Analysis of gene diversity in subdivided populations. Proc. Natl. Acad. Sci. U.S.A. 70, 3321-3323.

Nei, M., 1987. Molecular Evolutionary Genetics. Columbia University Press.

Nei, M., Li, W.H., 1979. Mathematical model for studying genetic variation in terms of restriction endonucleases. Proc. Natl. Acad. Sci. U.S.A. 76, 52695273.

Neuhaus, D., Kühl, H., Kohl, J.G., Doerfel, P., Borner, T., 1993. Investigation on the genetic diversity of reed stands using genetic fingerprinting and random amplified polymorphic DNA (RAPD). Aquat. Bot. 45, 357-364.

Nybom, H., Bartish, I.V., 2000. Effects of life history traits and sampling strategies on genetic diversity estimates obtained with RAPD markers. Perspect. Plant Ecol. Evol. Syst. 3/2, 93-114.

Rogers, S.O., Bendich, A.J., 1985. Extraction of DNA from milligram amounts of fresh, herbarium and mummified plant tissues. Plant Mol. Biol. 5, 69-76.

Saltonstall, K., 2002. Cryptic invasion by a non-native genotype of the common reed, Phragmites australis, into North America. Proc. Natl. Acad. Sci. U.S.A. 99, 2445-2449.

Schneider, S., Roessli, D., Excoffier, L., 2000. Arlequin: A Software for Population Genetic Data. Genetics and Biometry Laboratory, University of Geneva, Switzerland.

Solè, M., Durka, W., Eber, S., Brandl, R., 2004. Genotypic and genetic diversity of the Common Weed Cirsium arvense (Asteraceae). Int. J. Plant Sci. 165, 437-444.

Smouse, P.E., Long, J.C., Sokal, R.R., 1986. Multiple regression and correlation extensions of the Mantel Test of matrix correspondence. Syst. Zoo. $35,627-632$.

Swofford, D.L., 1998. PAUP. Phylogenetic Analysis Using Parsimony (and other methods). Version 4. Sinauer Associates, Sunderland, Massachusetts.

Tero, N., Aspi, J., Siikamäki, A., Jäkäläniemi, A., Tuomi, J., 2003. Genetic structure and gene flow in a metapopulation of an endangered pland species, Silene tatarica. Mol. Ecol. 12, 2073-2085.

Watkinson, A.R., Powell, J.C., 1993. Seedling recruitment and the maintenance of clonal diversity in plant populations-a computer simulation of Ranunculus repens. J. Ecol. 81, 707-717.

Weir, B.S., Cockerham, C.C., 1984. Estimating F-statistics for the analysis of population structure. Evolution 38, 1358-1370.

Weisner, S.E.B., Graneli, W., Ekstam, B., 1993. Influence of submergence on growth of seedlings of Scirpus lacustris and Phragmites australis. Freshwater Biol. 29, 371-375.

Yeh, F.C., Yang, R.C., Boyle, T., 1997. Popgene Version 1.32 ed., Software Microsoft Window-Based Freeware for Population Genetic Analysis. University of Alberta, Edmonton, Alta. 